\title{
Analisa Efektivitas Dan Efisiensi Pelaksanaan Anggaran Pendapatan Belanja Daerah Provinsi Sumatera Barat
}

\author{
Berta Agus Petra, Yosi Puspita Sari \\ Universitas Putra Indonesia YPTK Padang, Indonesia \\ E-mail: agusberta@upiyptk.ac.id
}

\begin{abstract}
Abstrak
Penelitian bertujuan untuk menganalisis bagaimana efektivitas dan efisiensi anggaran pendapatan dan belanja Provinsi Sumatera Barat khususnya pada Kota Padang. Objek pada penelitian ini adalah Badan Pengelolaan Keuangandan Aset Daerah ( BPKAD ) Kota Padang. Data yang digunakan dalam penelitian ini adalah laporan keuangan yang disusunoleh BPKAD Kota Padang selama 2 tahun( 2018-2019). Dari penelitian ini ditemukan bawah tingkat efektivitas pelaksanaan anggaran pendapatan belanja daerah Provinsi Sumatera Barat khususnya Kota Padang pada tahun 2018 cukup efektif sedangkan untuk tahun 2019 kurang efektif. Hal ini terlihat dari tingkaat efektivitas tahun 2018 sebesar 91,51\% sedangkan untuk tahun 2019 adalah sebesar $87,29 \%$. Sedangkan untuk tingkat efisiensi pelaksanaan anggran pendapatan belennya pada tahun 2018 kurang efisien dan untuk tahun 2019 cukup efisien. Ini dilihat dari hasil yang didapat dimana pada tahun 2018 nilai efisiennya 100,53\% dan pada tahun 2019 adalah $100 \%$.
\end{abstract}

\section{Kata kunci:Ektivitas, Efisiensi APBD Kota Padang $\backslash$}

\section{Pendahuluan}

Dalam era reformasi dan pelaksanaan otonomi daerah yang semakin meningkat seperti sekarang ini, membuat masyarakat semakin meningkatkan tuntutannya kepada Pemerintah, untuk menjalankan pemerintahan yang bersih. Untuk menjalankan Pemerintah yang bersih tersebut, seluruh anggaran dan keuangan pemerintah harus ada standar pencatatan yang sudah diatur dalam Sistem Akuntansi SektorPublik.

Pembangunan daerah diarahkan untuk mewujudkan visi bangsa yang telah dituangkan dalam garis- garis besar haluan Negara 1999-2004 yaitu : "terwujudnya masyarakat damai, demografis, berkeadilan berdaya saing, maju dan sejahtera dalam wadah negara kesatuan republik Indonesia". Seiring dengan visi tersebut undang-undang no. 22 tahun 1999 yang direvisi dengan undang-undang No. 32 tahun 2004 tentang pemerintahan daerah dan undang- undang No. 25 tahun 1994 yang disempurnakan dengan undang-undang No. 33 tahun 2004 tentang perimbangan keuangan pemerintah pusat dan pemerintah daerah undang-undang menempatkan otonomi daerah, secarah utuh ditujukan kepada kota / kabupaten provinsi, berdasarkan kepada Undang-Undang Dasar tahun 1945 ditentukan mengenai penyelenggaraan pemerintah Negara.

Laporan pertanggung jawaban kepada daerah pun nampaknya menjadi sangat strategis, lebih-lebih karena Dewan Perwakilan Rakyat Daerah (DPRD) yang semakin sadar akan hak konstitusionalnya, akan tetapi penyajian laporan pertanggung jawaban kepada daerah yang antara lain berisikan neraca, laporan perhitungan anggaran dan laporan arus kas masih sangat sulit disusun.

Indikator yang digunakan dalam pelaksanaan anggaran yang dilakukan oleh pemerintah adalah sebagai berikut:

1. Perbandingan antara anggaran danrealisasi

2. Perbandingan antara biaya danrealisasi

3. Target dan persentase fisik proyek yang terancam dalam penjabaran perhitungan APBD (Peraturan pemerintah no. 06 tahun 1972 tentang cara penyusunan APBD, pelaksanaan tata usaha keuangan daerah, penyusunan perhitunganAPBD).

Penelitian ini mengacu kepada penelitian yang dilakukan oleh Sari, Dwi Novita. Dkk (2018) dengan judul Analisis efektivitas dan efisiensi pelaksanaan anggaran belanja. Perbedaan penelitian ini dengan penelitian sebelumnya dimana penelitian ini hanya membahas mengenai 
dana desa sedangkan penelitian yang dilakukan ini membahas mengenai anggaran pendapatan belanja daerah kota padang, dengan skop yang lebih besar. Objek penelitian juga berbedah dengan penelitian sebelumnya dimana penelitian ini dilakukan pada Kota Padang sedangkan penelitian yang dilakukan oleh Sari, Dwi Novita dkk, itu dilakukan Pemerintahan Kota Samarinda.

Penelitian yang berhubungan dengan penelitian ini juga pernah dilakukan oleh Siregar, Fachrul A dan Fazli Syam (2017) dengan judul analisis efektifitas dan efisiensi pengelolaan keuangan desa (studi pada desa di kabupaten deli serdang). Penelitianya lebih terfokus pada dana desa sedangakn untuk penelitian ini lebih kepada Pemerintahan Daerah Kota Padang.

\section{Metodologi Penelitian}

Jenis penelitian yang digunakan dalam penelitian ini adalah penelitian deskriptif. Metode penelitian deskriptif adalah salah satu metode penelitan yang banyak digunakan pada penelitian yang bertujuan untuk menjelaskan suatu kejadian. Seperti yang dikemukakan oleh Sugiyono (2016). Teknik pengampilan data dalampeneliltian ini adalah pergi kelapangan dengan meminta laporan keuangan Pemerintah Provinsi Sumatera Barat khususnya pada Kota Padang selama 2 tahun berturut-turut 2018-2019. Metodologi yang diterapkan dalam melaksanakan penelitian harus dijelaskan dengan baik.

\section{Variabel penelitian:}

\section{a. Efiektivitas}

Dalam penelitian efektivitas diukur dengan menggunkan rumus:

$$
\text { Efektivitas anggaran pendapatan }=\frac{\text { realisasi anggaran pendapatan }}{\text { anggaran pendapatan }} \times 100 \%
$$

Kriteria pengukuran tingkat efektivitas dapat dilihat pada Tabel 1 sebagai berikut:

Tabel .1

Kriteria Efektivitas

\begin{tabular}{|c|c|}
\hline Persentase & Kriteria \\
\hline$>100 \%$ & Sangat efektif \\
$100 \%$ & Efektif \\
$90 \%-99 \%$ & Cukup efektif \\
$75 \%-89 \%$ & Kurang efektif \\
$<75 \%$ & Tidak efektif \\
\hline
\end{tabular}

\section{Sumber :Mahmudi (2011:171)}

\section{b. Efisiensi}

Rumus untuk mengukur tingkat efiseinsi alah sebaga berikut:

$$
\text { Efisiensi anggaran pendapatan }=\frac{\text { biaya pemerolehan pendapatan }}{\text { realisasi anggaran pendapatan }} \times 100 \%
$$

Sementara itu kriteria pengukuran tingkat efisiensi dapat dilihat pada Tabel 2 sebagai berikut:

Tabel 3

Kriteria Efisiensi

\begin{tabular}{|c|c|}
\hline Persentase & Kriteria \\
\hline Lebih dari $100 \%$ & Kurang efisien \\
Sama dengan $100 \%$ & Cukup efisien \\
Kurang dari $100 \%$ & Efisien \\
\hline
\end{tabular}

Sumber :Mahmudi (2011:171) 


\section{Hasil dan Pembahasan}

\section{Analisa Penyusunan Anggaran Pendapatan}

Analisa penyusunan anggaran pendapatan ini bertujuan untuk mengetahui bagaimana anggaran yang disusun oleh Pemerintahan Kota Padang terealisasi dengan baik.

Table 3 :Anggaran Dan Realisasi Anggaran Pendapatan Pemerintahan Kota Padang Tahun Anggaran 2007-2011

\begin{tabular}{|c|c|c|c|}
\hline $\begin{array}{c}\text { Tahun } \\
\text { Anggaran }\end{array}$ & Anggaran & $\begin{array}{c}\text { Realisasi anggaran } \\
\text { pendapatan }\end{array}$ & $\begin{array}{c}\text { Persenta } \\
\text { se }\end{array}$ \\
\hline$(1)$ & (2) & $(3)$ & $\begin{array}{c}(4)=(3): \\
(2)\end{array}$ \\
\hline 2018 & 2.360 .791 .801 .476 & 2.160 .375 .621 .454 & $91,91 \%$ \\
\hline 2019 & 2.692 .438 .463 .837 & 2.350 .116 .615 .606 & $87,29 \%$ \\
\hline \multicolumn{3}{|c|}{ Rata-rata } & $89,6 \%$ \\
\hline
\end{tabular}

Sumber :APBD Pemerintah Kota Padang Tahun 2019-2019 (Data diolah)

Kebijakan umum dalam perencanaan pendapatan asli daerah dapat diuraikan sebagai berikut :

Anggaran pendapatan asli daerah ditetapkan secara rasional dengan mempertimbangkan realisasi tahun lalu, potensi, dan asumsi pertumbuhan ekonomi yang dapat mempengaruhi terhadap jenis penerimaan, objek penerimaan serta rincian objek penerimaan.

Dari tabel 3 dapat dilihat penyusunan anggaran pendapatan dan realisasi tahun 2018-2019 sebagai berikut:

1. Anggaran pendapatan tahun 2018. Anggaran pendapatan tahun 2018 adalah sebesar Rp. Rp 2.360.791.801.476, sedangkan realisasinya sebesar Rp 2.160.375.621.454. Ini artinya realisasi anggaran pendapatannya lebih kecil dari pada anggarannya sendiri yaitu sebesar (Rp. 200.416.180.021). Hal ini kurang bagus, karena Pemerintah Kota Padang tidak dapat mencapai anggaran pendapatannya, bahkan kurang dari yang dianggarkannya. Persentase dari realisasi anggaran pendapatan terhadap anggarannya sebesar 91,91\%\%, hal ini menujukkan bahwa anggaran tahun 2018 terealisasi dengan kurang baik.

2. Anggaran pendapatan tahun 2019. Anggaran pendapatan pada tahun 2019 adalah sebesar Rp 2.692.438.463.837, sedangkan realisasinya sebesar Rp. 2.350.116.615.606. Ini artinya realisasi anggaran pendapatannya lebih kecil dari pada anggarannya sendiri yaitu sebesar (Rp. 342.321.848.230). Hal ini kurang bagus, karena Pemerintah Kota Padang tidak dapat mencapai anggaran pendapatan yang dianggarkannya. Persentase dari realisasi anggaran pendapatan terhadap anggarannya sebesar $87,6 \%$, hal ini menunjukkan bahwa anggaran tahun 2019 terealisasi dengan kurang baik.

Berdasarkan hasil penelitian yang telah dilakukan, maka penulis dapat diinterprestasikan hal-hal sebagai berikut:

a. Tingkat efektivitas anggaran Pendapatan Asli Daerah (PAD) Pemerintah Kota Padang Tahun Anggaran 2018-2019.

Tingkat efektivitas anggaran Pendapatan Asli Daerah (PAD) dapat diketahui dengan menggunakan rasio efektivitas, yaitu rasio yang menggambarkan kemampuan pemerintah daerah dalam merealisasikan anggaran Pendapatan Asli Daerah (PAD) yang direncanakan dibandingkan dengan anggaran yang ditetapkan berdasarkan potensi riil daerah. 
Tabel 4.

Anggaran dan Realisasi Pendapatan

\begin{tabular}{|c|c|c|c|c|c|}
\hline $\begin{array}{c}\text { Tahun } \\
\text { Anggaran }\end{array}$ & & Anggaran & & $\begin{array}{c}\text { Realisasi anggaran } \\
\text { pendapatan }\end{array}$ & $\begin{array}{c}\text { Persent } \\
\text { ase }\end{array}$ \\
\hline (1) & & (2) & & $(3)$ & $\begin{array}{l}(4)= \\
(3):(2)\end{array}$ \\
\hline 2018 & $\mathrm{Rp}$ & 2.360 .791 .801 .476 & $\mathrm{Rp}$ & 2.160 .375 .621 .454 & $91,51 \%$ \\
\hline 2019 & $\mathrm{Rp}$ & 2.692 .438 .463 .837 & $\mathrm{Rp}$ & 2.350 .116 .615 .606 & $87,29 \%$ \\
\hline
\end{tabular}

Sumber :APBD Pemerintah Kota Padang

Anggaran pendapatan tahun 2018 adalah sebesar Rp. 2.360.791.801.476 sedangkan realisasinya sebesarRp.2.160.375.621.454. Ini artinya realisasi anggaran pendapatannya lebih kecil dari pada anggarannya sendiri yaitu sebesar Rp. 200.416.180.021. Hal ini cukup efektif, karena walaupun pemerintah Kota Padang tidak dapat mencapai 100\% dari anggarannya namun Pemerintah Kota Padang dapat mencapai anggaran pendapatannya, sebesar 91,51\%. Berdasarkan kriteria ini masih tergolong efektif.

Sedangkan untuk anggaran pendapatan tahun 2019. Anggaran pendapatan pada tahun 2018 adalah sebesar Rp. 2.692.438.463.837, sedangkan realisasinya sebesar Rp.2.350.116.615.606. Ini artinya realisasi anggaran pendapatannya lebih kecil dari pada anggarannya sendiri yaitu sebesar (Rp. 342.321.848.230). Hal ini kurang efektif, karena Pemerintah Kota Padang tidak dapat mencapai anggaran pendapatan yang dianggarkannya. Persentase dari realisasi anggaran pendapatan terhadap anggarannya sebesar $87,29 \% \%$, hal ini menunjukkan bahwa anggaran tahun 2019kurang terealisasi dengan baik.

Jika dibandingkan antara tahun 2018 dan tahun 2019, kinerja Pemerintah Kota Padang pada tahun 2018 ; lebih bagus dari pada tahun 2019. Ini dapat dilihat dari persentai perbandingan antara anggaran dan realisasi pertahunnya. Dan untuk prediksi tahun 2020 pemerintahan Kota Padang akan mengalami penurunan lagi yang di sebabkan oleh wabah Covid-19.

b. Tingkat efisiensi anggaran Pendapatan Asli Daerah (PAD) Pemerintah Kota Padang Tahun Anggaran 2018-2019.

Analisis tingkat efisiensi pendapatan daerah dapat dihitung dengan menggunakan rasio efisieasi, yaitu rasio yang menggambarkan perbandingan antara output dan input atau realisasi biaya memperoleh pendapatan dengan realisasi anggaran pendapatan. Menurut Mahmudi (2011: 171) rasio efisiensi pendapatan daerah dapat diukur dengan :

$$
\text { Efisiensi anggaran pendapatan }=\frac{\text { biaya pemerolehan pendapatan }}{\text { realisasi anggaran pendapatan }} \times 100 \%
$$

Tabel 4

Tingkat efisiensi pengelolaan keuangan daerah Pemerintah kota Padang disajikan pada

Tabel 5

Anggaran dan Realisasi Biaya

\begin{tabular}{cllccc}
\hline Tahun & Realisasi Anggaran Pendapatan & & Realisasi Biaya Memperoleh & Pendapatan & Persentase \\
\hline 2018 & $\mathrm{Rp}$ & 2.160 .375 .621 .454 & $\mathrm{Rp}$ & 2.171 .972 .844 .481 & $100,53 \%$ \\
\hline 2019 & $\mathrm{Rp}$ & 2.350 .116 .615 .606 & $\mathrm{Rp}$ & 2.351 .499 .268 .939 & $100 \%$ \\
\hline
\end{tabular}

Sumber :APBD Pemerintah Kota Padang

Berdasarkan Tabel di atas dapat diketahui bahwa tingkat efisiensi rata-rata Pemerintah Kota Padang Pada Tahun Anggaran 2018 sebesar 100,53 \%. Sedangkan untuk tahun 2019 ada pada angka 100\%. Berdasarkan kriteri pada tahun 2018 kinerja dari Pemerintahan Kota Padang kurang efisien karena berada pada angka lebih dari 100\% sedangkan untuk tahun 2019 cukup efissien karena tingkat efisiensinya berada pada angka 100\%. Pada tahun 2018 kurang efisien. 
Pada tabel 4. juga menunjukkan bahwa rasio efisiensi dari tahun 2018-2019 masih stabil. Dimana dapat dilihat pada tahun 2018 dan 2019 rasio efisiensinya secara berturut-turut sebesar $100,53 \%$, dan $100 \%$ yang berarti realisasi anggaran pendapatan lebih kecil dari pada biaya memperoleh anggaran pendapatan tersebut.

\section{Kesimpulan}

Berdasarkan hasil penelitian yang dilakukan pada BPKAD (Badan Pengelolaan Keuangan dan Aset Daerah)Provinsi Sumatera Barat khususnya pada Kota Padang periode anggaran20182019 maka dapat ditarik kesimpulan bahwa Tingkat efektivitas anggaran Pendapatan Asli Daerah (PAD) Pemerintah Kota Padang, Jika dibandingkan antara tahun 2018 dan tahun 2019, kinerja Pemerintah Kota Padang pada tahun 2018 ; lebih bagus dari pada tahun 2019. Ini dapat dilihat dari persentase perbandingan antara anggaran dan realisasi pertahunnya. Dan untuk prediksi tahun 2020 pemerintahan Kota Padang akan mengalami penurunan lagi yang di sebabkan oleh wabah Covid-19. Sedangkan Tingkat efisiensi anggaran Pendapatan Asli Daerah (PAD) Pemerintah Kota Padang Tahun Anggaran 2018-2019.Diketahui bahwa tingkat efisiensi rata-rata Pemerintah Kota Padang Pada Tahun Anggaran 2018 lebi dari 100\%. Sedangkan untuk tahun 2019 ada pada angka 100\%. Berdasarkan kriteri pada tahun 2018 kinerja dari Pemerintahan Kota Padang kurang efisien karena berada pada angka lebih dari 100\% sedangkan untuk tahun 2019 cukup efissien karena tingkat efisiensinya berada pada angka $100 \%$.

\section{Daftar Pustaka}

Beni Pekei. 2016. Konsep dan Analisis Efektivitas Pengelolaan Keuangan Daerah di Era Otonomi. Buku 1.Jakarta Pusat : Taushia

Mahmudi. (2011). Akuntansi Sektor Publik. Yogyakarta: UII Press Yogyakarta.

Nordiawan, deddi dan Ayuningtyas herianti. (2011). Akuntansi Sektor Publik. Jakarta: salemba Empat.

Novrinta, A. D. (2011). Hubungan Antara Pengetahuan Dan Perilaku Menjaga Kebersihan Genetalia Eksterna Dengan Kejadian Keputihan Pada Siswi SMA Negeri 4 Semarang. Fk Undip.

Sari, D. N. (2018). Analisis efektivitas dan efisiensi pelaksanaan anggaran belanja. Akuntansi, 1,1 . Siregar, F. A., \& BZ, F. S. (2017). Analisis Efektifitas dan Efisiensi Pengelolaan Keuangan Desa (Studi pada Desa Di Kabupaten Deli Serdang). Jurnal Ilmiah Mahasiswa Ekonomi Akuntansi. Sugiyono, P. D. (2016). metode penelitian kuantitatif, kualitatif,dan R\&D. In Alfabeta, $c v$.

Sujarweni Wiratna. (2015). Metodologi Penelitian - Bisnis dan Ekonomi. In Metodologi Penelitian. https://doi.org/10.1145/2505515.2507827 